\title{
PENGARUH KEBERADAAN GAPOKTAN TERHADAP PENDAPATAN PETANI DAN PERUBAHAN TUTUPAN LAHAN DI HUTAN KEMASYARAKATAN
}

\author{
Rahmat Safe'i, Indra Gumay Febryano dan Lina Nur Aminah \\ Jurusan Kehutanan dan Magister Kehutanan Universitas Lampung \\ E-mail: Linanuraminah@gmail.com
}

\begin{abstract}
ABSTRAK. Hutan Kemasyarakatan (HKm) adalah hutan negara yang pemanfaatan utamanya ditujukan untuk memberdayakan masyarakat di dalam dan sekitar kawasan hutan. Dengan adanya program HKm masyarakat dan pemerintah dapat bersama-sama menjaga kelestarian hutan. Masyarakat sebagai pelaku utama dalam pengelolaan HKm merasakan dampak yang besar. Dengan adanya program HKm masyarakat memiliki akses untuk dapat memanfaatkan hasil hutan non kayu yang dapat membantu masyarakat dalam meningkatkan pendapatan ekonomi. Penelitian ini bertujuan untuk melihat pengaruh keberadaan gapoktan terhadap peningkatan ekonomi masyarakat pengelola lahan HKm serta melihat perbedaan tutupan lahan diareal kerja gapoktan sebelum dan sesudah terbentuknya gapoktan. Metode yang digunakan dalam penelitian ini adalah observasi partisipan, wawancara mendalam, dan analisis dokumen. Hasil penelitian menunjukan bahwa Pendapatan anggota di kedua gapoktan cenderung mengalami peningkatan. Pendapatan anggota Gapoktan Beringin Jaya mengalami peningkatan dari rata-rata Rp. 25.473.684/ha/tahun menjadi rata-rata Rp. 29.368.421/ha/ tahun. Pendapatan anggota di Gapoktan Sinar Mulya juga meningkat dari rata-rata Rp. 31.416.66/ha/tahun menjadi Rp. 37.054.042/ha/ tahun. Perubahan tutupan lahan di areal kerja kedua gapoktan mengalami perubahan yaitu semakin meluasnya areal pertanian dan lahan terbuka pada areal kerja gapoktan.
\end{abstract}

Kata kunci: Hutan Kemasyarakatan (HKm), Perubahan tutupan lahan, Pendapatan petani.

\section{EFFECT OF THE EXISTENCE GAPOKTAN TO FARMER INCOME AND LAND COVER CHANGE IN COMMUNITY FOREST}

\begin{abstract}
Community Forest (HKm) is a state forest whose main use is to empower communities in and around forest areas. With the community forestry program and the government can work together to preserve the forest. The community as the main actors in the management of community forest feel a great impact. With the community forestry program the community has access to utilize non-timber forest products that can help the community in increasing the economic income. This study aims to see the effect of the combined presence of farmer groups on improving the economics of community forest managers and to see the difference of land cover in gapoktan working area before and after the formation of gapoktan. The methods used in this research are participant observation, indepth interview, and document analysis. The results showed that the income of the members in both gapoktan tend to increase. Gapoktan Beringin Jaya member's income increased from an average of Rp. 25.473.684 / ha / year to an average of Rp. 29.368.421 / ha / year. Revenue members in Gapoktan Sinar Mulya also increased from an average of Rp. 31.416.66 / ha / year to Rp. 37.054.042 / ha / year. Changes in land cover in the second work area gapoktan change that is the increasingly widespread agricultural area and open land in the working area of gapoktan.
\end{abstract}

Key words: Community Forest (HKm), Change of land cover, Farmers income.

\section{PENDAHULUAN}

Hutan kemasyarakatan (HKm) merupakan hutan negara yang pemanfaatan utamanya ditujukan untuk memberdayakan masyarakat setempat dalam upaya untuk meningkatkan kemampuan dan kemandirian masyarakat untuk mendapatkan manfaat sumberdaya hutan secara optimal dan adil melalui pengembangan kapasitas dan pemberian akses dalam rangka peningkatan kesejahteraan masyarakat setempat (Dephut, 2007). HKm merupakan salah satu program pemerintah untuk melibatkan masyarakat dalam melakukan pengelolaan kawasan secara bersama-sama (Dephut, 2007). Program ini ditetapkan Menteri Kehutanan melalui Peraturan Menteri Kehutanan No: P.37/MENHUT-II/2007 yang kemudian di revisi melalui Peraturan Menteri Kehutanan No: P.18/MENHUT-II/2009 dan Peraturan Menteri Kehutanan No: P.13/MENHUT-II/2010. Dalam peraturan-peraturan tersebut diatur segala sesuatu tentang bentuk pelaksanaan program $\mathrm{HKm}$.

HKm memberikan keuntungan tersendiri baik bagi masyarakat sekitar hutan, maupun pemerintah. Dengan adanya program HKm yang dikeluarkan oleh pemerintah, hal tersebut dapat mencegah terjadinya degradasi kawasan hutan dikarenakan banyaknya pembalakan liar yang dilakukan oleh masyarakat swekitar kawasan hutan. Dengan adanya program HKm masyarakat dan pemerintah dapat bersama-sama menjaga kelestarian hutan. Masyarakat sebagai pelaku utama dalam pengelolaan HKm merasakan dampak yang besar. Masyarakat memiliki akses untuk dapat memanfaatkan hasil hutan non kayu, hal tersebut dapat membantu masyarakat dalam meningkatkan kesejahteraan dan kapasitas ekonomi.

Dalam pengelolaan lahan HKm upaya pelibatan masyarakat dilakukan dengan memperkuat kelembagaan masyarakat. Dengan adanya kelembagaan pada kelompok tani $\mathrm{HKm}$ dapat menjadi dasar dalam melaksanakan 
setiap program yang ada di dalam kelompok tersebut. Partisipasi aktif masyarakat pengelola lahan HKm dalam kelembagaan dapat memberikan dampak baik positif maupun dampak negatif terhadap prilaku masyarakat dalam mengelola lahan HKm. Dampak tersebut dapat dilihat dari kondisi tutupan lahan HKm sebelum dan sesudah adanya program $\mathrm{HKm}$ di wilayah tersebut, keberhasilan masyarakat dalam mengelola lahan HKm dapat dilihat juga dari adanya peningkatan pendapatan yang diperoleh oleh masyarakat.

Dalam pengelolaan $\mathrm{HKm}$ dibutuhkan sistem pengelolaan yang terencana yang mendukung pelaksanaan kegiatan pengelolaan HKm itu sendiri, karena pengelolaan HKm yang dilakukan secara personal akan berbeda dengan pengelolaan secara kelompok. Pengelolaan HKm akan berjalan dengan baik melalui sebuah wadah yaitu berupa kelompok tani/ kelompok tani hutan. Kelompok tani merupakan sebuah kelembagaan di tingkat petani yang secara langsung berperan dalam kegiatannya mengembangkan unit usaha secara bersama dan di dalamnya terjadi interaksi dan koordinasi antar anggota sehingga tujuan bersama akan cepat tercapai. Keberadaan kelembagaan kelompok tani dijadikan suatu wadah oleh anggota kelompok dalam menjalankan suatu program dimana kelompok memiliki aturan main dalam mengelola dan menggarap lahan HKm. Menurut Hermanto et al. (2007) menyebutkan partisipasi aktif petani dalam kegiatan kelembagaan memberikan dampak positif yaitu berupa peningkatan pendapatan dari usaha tani yang sangat signifikan. Keberadaan gapoktan seharusnya dapat memberikan dampak positif bagi anggota dan keberadaan hutan itu sendiri. Masyarakat tetap dapat memperoleh peningkatan pendapatan dari pemanfaatan keberadaan lahan $\mathrm{HKm}$ dengan tetap memperhatikan kelestarian lahan HKm itu sendiri. Menurut Purwita et al (2009) menyebutkan bahwa pendapatan yang rendah merupakan salah satu faktor pendorong untuk melakukan kegiatan perambahan di dalam hutan. Kemiskinan merupakan faktor paling berpengaruh terhadap sumberdaya hutan Dien (2004). Penelitian ini bertujuan untuk melihat peran keberadaan suatu kelembagaan gapoktan dalam melakukan kontrol terhadap masyarakat pengelola lahan HKm sehingga masyarakat tetap memperoleh peningkatan pendapatan sedangkan keberadaan lahan HKm tetap terjaga kelestariannya.

\section{METODE}

Penelitian dilakukan di Gapoktan Beringin Jaya (berada di Pekon Margoyoso Kecamatan Sumberejo) dan Gapoktan Sinar Mulya (berada di Pekon Sukamaju Kecamatan Ulu Belu) Kabupaten Tanggamus Provinsi Lampung. Alasan pemilihan lokasi penelitian tersebut dikarenakan kedua gapoktan merupakan gapoktan yang mengelola lahan HKm. Gapoktan Beringin Jaya merupakan gapoktan yang sudah berhasil dalam mengelola HKm. HKm Beringin Jaya merupakan HKm yang memperoleh penghargaan sebagai pengelola $\mathrm{HKm}$ terbaik pada tahun 2016 dari Kementerian Lingkungan Hidup dan Kehutanan. Sedangkan Gapoktan Sinar Mulya merupakan gapoktan yang sampai saat ini belum terlihat prestasinya. Kedua gapoktan ini berdiri pada waktu yang hampir bersamaan dibawah pendampingan Konsorsium Kota Agung Utara. Untuk melihat apakah keberadaan gapoktan dampak memberikan dampak baik bagi peningkatan pendapatan maupun kelestarian keberadaan lahan HKm di kedua gapoktan maka perlu dilakukan analisi pendapatan dan analisi perubahan tutupan lahan di kedua areal kerja gapoktan.

Penelitian ini merupakan penelitian kualitatif. Pengumpulan data dilakukan melalui observasi partisipan, wawancara mendalam, Mendownload citra landsat Pengamatan dengan menggunakan software arc view dan analisis dokumen. Penelitian ini di laksanakan pada Bulan Januari-Februari 2017. Responden dalam penelitian ini adalah 43 orang dari total sample 1272 orang (Gapoktan Beringin Jaya sebanyak 571 dan Sinar Mulya sebanyak 701 petani). Menurut Arikunto (2000) jika populasi lebih dari 100 maka batas error yang digunakan adalah $10-15 \%$. Berdasarkan ketetapan batas error yang telah disebutkan maka, batas error yang digunakan dalam penelitian ini adalah $15 \%$ karena lebih menunjang data. Rumus dalam penentuan sampel menggunakan rumus: Keterangan :

$$
\begin{array}{ll}
n & : \text { Jumlah responden } \\
\mathrm{N} & : \text { Jumlah total petani pengelola lahan HKm } \\
\mathrm{e} & : \text { Presisi } 15 \% \\
n & : \frac{1272}{1272(15 \%)^{2}+1} \frac{1272}{1272(15 \%)^{2}+1} \\
n & : 43 \text { responden }
\end{array}
$$

Jumlah responden masing-masing Gapoktan dihitung dengan rumus (Sugiyono,2007): $n=\frac{N i}{N} \frac{N i}{N} \times n i$

\section{Keterangan:}

$\mathrm{n} \quad=$ jumlah sampel yang akan diambil.

$\mathrm{N}$ = jumlah total populasi pada kedua Gapoktan.

$\mathrm{Ni}=$ jumlah populasi pada masing-masing Gapoktan (i).

ni = jumlah responden dari masing-masing Gapoktan.

Tabel 1. Jumlah sampel di Gapoktan Beringin Jaya dan Sinar Mulya

\begin{tabular}{llcc}
\hline No & Nama Gapoktan & Jumlah Anggota & $\begin{array}{c}\text { Jumlah } \\
\text { Responden }\end{array}$ \\
\hline 1 & Beringin Jaya & 571 & 19 \\
2 & Sinar Mulya & 701 & 24 \\
\hline
\end{tabular}

Sampel dipilih dengan cara purposive dengan pertimbangan bahwa sampel yang dipilih merupakan petani yang mengelola lahan HKm di Gapoktan Beringin Jaya dan Sinar Mulya. Analisis data yang dilakukan meliputi analisis penutupan lahan dan analisis pendapatan petani dari lahan $\mathrm{HKm}$. Analisis yang dilakukan pada 
perubahan tutupan lahan meliputi: (1) pemulihan citra, (2) penajaman citra (image enhancement), (3) pemotongan citra (Subset image), (4) klasifikasi citra (Image classifcation), (5) accuracy assesement, (6) overlay hasil klasifikasi, (7) tabulasi data, (8) analisis deskriptif dan kuantitatif (Darmawan, 2002). Sedangkan analisis pendapatan dilakukan dengan cara menghitung pendapatan yang diterima dari lahan HKm dikurangi biaya yang dikeluarkan untuk pengelolaan lahan HKm.

\section{HASIL DAN PEMBAHASAN}

Hutan Kemasyarakatan (HKm) adalah hutan negara yang pemanfaatan utamanya ditujukan untuk memberdayakan masyarakat di dalam dan sekitar kawasan hutan. Pemberdayaan masyarakat dilihat sebagai upaya meningkatkan kemampuan dan kemandirian masyarakat agar mereka mendapatkan manfaat sumber daya hutan secara optimal dan adil melalui pengembangan kapasitas dan pemberian akses dalam rangka kesejahteraan masyarakat.

HKm hanya diberlakukan di kawasan hutan lindung dan dalam pemanfaatan hasil hutan dimana kawasan tersebut menjadi sumber mata pencaharian masyarakat setempat. Izin Usaha Pemanfaatan Pengelolaan HKm (IUPHKm) diberikan untuk jangka waktu 35 tahun dan diperpanjang sesuai dengan hasil evaluasi setiap 5 tahun. HKm diperuntukkan bagi masyarakat miskin yang tinggal di dalam dan sekitar kawasan hutan serta menggantungkan penghidupannya dari memanfaatkan sumberdaya hutan. Pelaksanaan $\mathrm{HKm}$ dapat dipilah dalam 3 tingkatan: pertama, penetapan yang dilakukan oleh pemerintah pusat (Kementerian Kehutanan); kedua, perizinan yang dilakukan oleh pemerintah daerah (bupati/ walikota/gubernur); dan ketiga, pengelolaan di lapangan yang dilakukan oleh kelompok masyarakat pemegang izin usaha pemanfaatan hutan kemasyarakatan.

Hutan Kemasyarakatan merupakan suatu program yang secara langsung melibatkan masyarakat dalam pemanfaatan sumber daya hutan dengan pengelolaaan yang mengkedepankan aspek keberlanjutan. Karena suatu hal yang tidak dapat diabaikan bahwa keberadaan kawasan hutan dengan berbagai potensi keanekaragaman hayatinya, adalah sebagai penyangga kehidupan umat manusia baik masyarakat disekitarnya maupun masyarakat pada umumnya.

KPH IX Kota Agung Utara aktif dirambah oleh masyarakat sekitar kawasan hutan, sebelum terbentuknya gapoktan sebagai wadah bagi petani pengelola lahan HKm. Kesadaran dari beberapa masyarakat disekitar kawasan hutan tentang pentingnya keberadaan hutan, mereka mengajak masyarakat lain untuk menjaga keberadaan kawasan lindung tersebut.

Keberadaan gapoktan diharapkan dapat memberikan dampak yang baik bagi peningkatan ekonomi anggotanya dengan tetap menjaga kelestarian di areal $\mathrm{HKm}$, karena dalam kegiatan kelembagaan gapoktan anggota diberikan pelatihan-pelatihan yang bertujuan untuk meningkatkan ekonomi anggotanya, dengan tetap memperhatikan aspek konservasinya. Berikut hasil penelitian berdasarkan wawancara dengan responden terkait dengan pendapatan anggota gapoktan dari lahan HKm. Gapoktan Beringin Jaya dan Sinar Mulya merupakan 2 dari 14 gapoktan yang mengelola lahan HKm di Wilayah KPHL Kota Agung Utara. Kedua gapoktan tersebut memiliki sistem kelembagaan yang berbeda satu sama lainnya, sehingga menyebabkan perbedaan kinerja yang dicapai. Pengertian kelembagaan dalam penelitian ini mengacu kepada beberapa definisi umum yang digunakan selama ini. Kartodihardjo (2006) mendefinisikan kelembagaan sebagai perangkat lunak, aturan main, keteladanan, rasa percaya, dan konsistensi kebijakan yang diterapkan di dalamnya. Schmid (2004) mengartikan kelembagaan sebagai seperangkat ketentuan yang tersedia, merumuskan bentuk kegiatan yang dapat dilakukan oleh pihak tertentu terhadap pihak lainnya.

Gapoktan Beringin Jaya merupakan gabungan dari delapan kelompok tani yang anggotanya merupakan penggarap lahan HKm di register 30 wilayah KPHL Kota Agung Utara adapun kelompok tani yang tergabung di dalam Gapoktan Beringin Jaya adalah Kelompok Tani Lestari Jaya 1, Lestari Jaya 2, Lestari Jaya 3, Lestari Jaya 4, Lestari Jaya 5, Lestari Jaya 6, Lestari Jaya 7 dan Lestari Jaya 8. Gapoktan Beringin Jaya terbentuk pada tahun 2009. Gapoktan ini menerima penyerahan izin penetapan peta areal kelola HKm dari menteri kehutanan dan pada tahun 2013 dengan nomor SK.886, Menhut-II,2013 dan pada tahun 2014 menerima izin usaha pemanfaatan HKm pada kawasan hutan lindung di Kabupaten Tanggamus dengan luas 871 ha dan jumlah anggota sebanyak 571 KK dari Bupati Tanggamus dengan No SK. B.465/34/ II/2014.

Gapoktan Sinar Mulya merupakan sebuah organisasi gabungan dari lima kelompok tani yang mengelola areal HKm yaitu Kelompok Tani Delong Selatan, Delong Tengah, Delong Utara, Lungur Buntung, dan Pondok Rejo. Gapoktan ini terbentuk pada tahun 2009 dan menerima penyerahan izin penetapan peta areal kelola HKm dari menteri kehutanan pada tahun 2012 dan pada tahun 2014 menerima izin usaha pemanfaatan $\mathrm{HKm}$ di register 39 Kota Agung Utara dengan luas 917 ha dari Bupati Tanggamus dengan No SK. 80. Menhut-II.2014.

Terbentuknya Gapoktan Beringin Jaya dan Sinar Mulya didasari oleh adanya kesamaan keinginan antar petani pengelola lahan HKm di Wilayah KPHL Kota Agung Utara untuk meningkatkan taraf hidup dan pendapatan keluarga, dari adanya tujuan yang sama antar anggota. Sebelum adanya Gapoktan, Kelompok-kelompok tani tersebut tidak berjalan dengan maksimal/jalan ditempat kemudian dengan adanya pendampingan dari KORUT (Konsorsium Kota Agung Utara), KPHL Kota Agung Utara, IPKINDO (Ikatan Penyuluh Kehutanan Indonesia), Forum HKM (terdiri dari pengurus tiap kelompok yang tergabung dalam 
gapoktan). dan PKSM (Penyuluh Kehutanan Swadaya Masyarakat) maka terbentuklah Gapoktan Beringin Jaya dan Sinar Mulya pada tahun 2009. Proses terbentuknya kedua gapoktan ini menentukan kekuatan kelompok yang terbentuk.

Keberlangsungan kedua gapoktan sampai saat ini tidak terlepas dari peran serta stakeholder dalam melakukan pendampingan terhadap kedua gapoktan. Pendampingan dari stakeholder yang terlibat memberikan dampak positif terhadap gapoktan. Gapoktan Beringin Jaya merupakan gapoktan yang dijadikan model percontohan oleh KORUT sehingga Gapoktan Beringin Jaya lebih maju dibandingkan dengan Gapoktan Sinar Mulya dan gapoktan yang lainnya. Pembangunan SDM ketika diimplementasikan dengan baik di dalam organisasi yang produktif, dapat secara langsung berkontribusi dalam peningkatan kinerja dan pencapaian tujuan organisasi (Swason dan Arnold 1996; Brown et al. 2000; Danish dan Usman 2010). Pendapat di atas sesuai dengan apa yang telah dilakukan Gapoktan Beringin Jaya. Gapoktan Beringin Jaya yang cenderung aktif dalam membangun SDM yang ada di dalamnya, menjadikan anggota gapoktan memiliki kemampuan yang lebih baik dalam hal pengelolaan $\mathrm{HKm}$. Kemampuan tersebut yang selanjutnya digunakan oleh gapoktan untuk pengembangan organisasi atau kelembagaan gapoktan. Dengan kemampuan yang lebih baik yang dimiliki, menjadikan gapoktan ini memperoleh penghargaan dari Kementerian Lingkungan Hidup dan Kehutanan sebagai pengelola lahan HKm terbaik pada tahun 2016 lalu.

Banyak faktor yang dapat mempengaruhi kinerja SDMdalammengelola lahan Hkm. Menurut(Syamsuddin 2006)adabeberapafaktoryangmempengaruhikualitasdan kuantitas kinerja individu dalam organisasi keterampilan, pengalaman, kesanggupan. Menurut Senoaji (2017) menyebutkan bahwa kualitas sumber daya manusia juga ditentukan oleh tingkat pendidikan. Pendidikan dipandang tidak hanya dapat menambah pengetahuan tetapi juga dapat meningkatkan keterampilan tenaga kerja sehingga akan meningkatkan produktivitas. Peningkatan produktivitas dapat meningkatkan pertumbuhan ekonomi dan meningkatkan penghasilan dan kesejahteraan. Menurut Sinaga (2016) Kelompok yang sumber dayanya terkelola dengan baik akan berdampak terhadap tingkat kesejahteraan kelompok itu sendiri. Kinerja Gapoktan Beringin Jaya dipengaruhi oleh aktif atau tidaknya pengurus dan anggota kelompok. Hal tersebut juga yang mendasari ketika pemilihan kepengurusan atau struktur gapoktan selain melalui seleksi juga harus melalui kesanggupan dari pihak yang terpilih.

Gapoktan Sinar Mulya merupakan salah satu gapoktan yang sedang merintis untuk dapat maju seperti Gapoktan Beringin Jaya. Saat ini Gapoktan Sinar Mulya masih pada tahap berkembang, dan dari segi kinerja belum terlalu memperlihatkan hasil, namun dengan mulai aktifnya kepengurusan Gapoktan Sinar Mulya mereka mengharapkan gapoktan ini dapat maju dan berkembang beberapa tahun kedepan. Saat ini gapoktan sedang berusa membuat perencanaan agar pengembangan ekowisata air terjun tersebut dapat memberikan dampak yang baik bagi seluruhh anggota Gapoktan Sinar Mulya.

Berdasarkan hasil perhitungan data kuesioner, pendapatan anggota dari kedua gapoktan cenderung mengalami peningkatan dari sebelum adanya gapoktan dibandingkan dengan kondisi saat ini setelah ada gapoktan. Pendapatan anggota Gapoktan Beringin Jaya mengalami peningkatan dari rata-rata Rp. 25.473.684/ ha/tahun menjadi rata-rata Rp. 29.368.421/ha/tahun. Pendapatan anggota di Gapoktan Sinar Mulya juga meningkat dari rata-rata Rp. 31.416.66/ha/tahun menjadi Rp. 37.054.042/ha/tahun. Peningkatan pendapatan tersebut berasal dari budidaya kopi dan tanaman MPTs di lahan gapoktan. Peningkatan pendapatan ekonomi anggota gapoktan ternyata tidak dibarengin dengan kondisi tutupan lahan di areal kerja kedua gapoktan.

Keberadaan gapoktan memberikan dampak positif terhadap peningkatan ekonomi anggotanya namun berdasarkan analisis citra terhadap tutupan lahan di areal kerja kedua gapoktan, tutupan lahan di areal kerja gapoktan cenderung berkurang. Penutupan lahan menggambarkan kontruksi vegetasi yang menutup permukaan tanah. Menurut Yusri (2011), penutupan lahan merupakan status lahan secara ekologi dan penampakan permukaan lahan secara fisik, yang dapat berubah karena adanya intervensi manusia, gangguan alam dan suksesi tumbuhan secara alami. Perubahan tutupan lahan di Gapoktan Beringin Jaya dapat dilihat pada Gambar 1 dan 2.

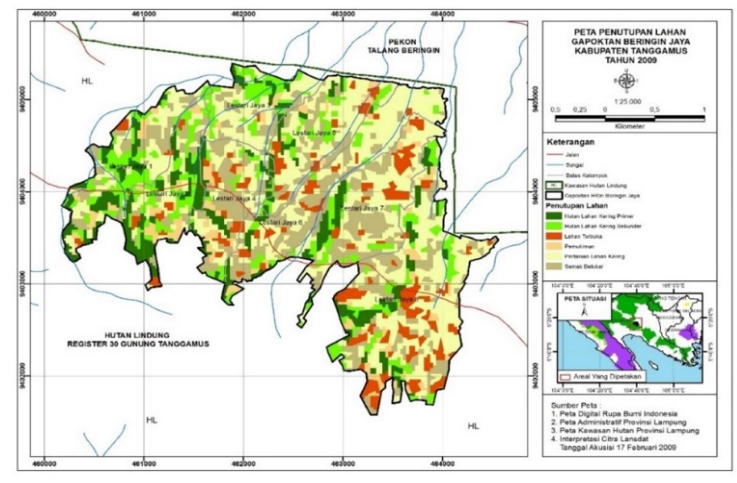

Gambar 1. Peta Tutupan Lahan Gapoktan Beringin Jaya 2009 (Sumber: Lina, 2017)

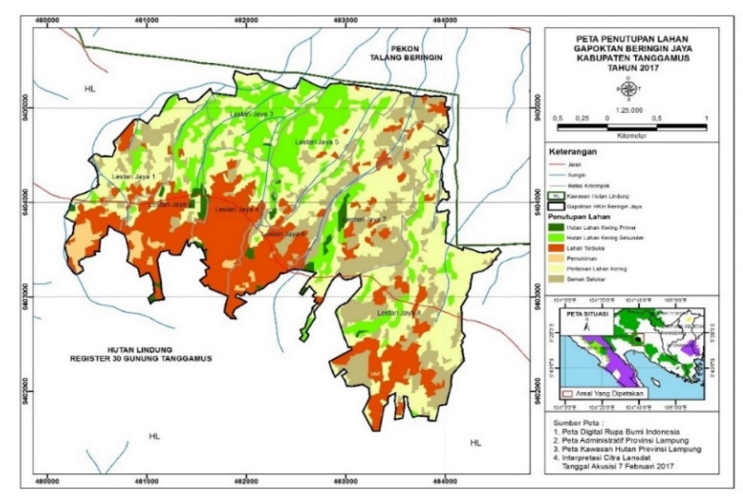

Gambar 2. Peta Tutupan Lahan Gapoktan Beringin Jaya 2017 (Sumber: Lina, 2017) 
Berdasarkan data di atas dapat dilihat bahwa perubahan tutupan lahan di areal kerja Gapoktan Beringin Jaya mengalami perubahan. Pada tahun 2009 hutan lahan kering primer sebesar 98.04 ha menjadi 13.79 ha pada tahun 2017. Hutan lahan kering sekunder dari 118 ha meningkat menjadi 140.57 ha. Lahan terbuka pada tahun 200976.04 ha meningkat menjadi 197.44 ha. Pemukiman penduduk di dalam kawasan berkurang dari 45.55 ha menjadi 17.24 ha. Pertanian lahan kering bertambah dari 327.92 ha menjadi 331.15 ha. Semak Belukar dari 188.29 ha berkurang menjadi 153.84 ha.

Kondisi perubahan tutupan lahan di areal kerja Gapoktan Beringin Jaya juga terjadi pada areal kerja Gapoktan Sinar Mulya, dimana kondisi lahan terbuka saat ini lebih besar dibandingkan pada tahun 2009 sebelum gapoktan terbentuk. Perubahan tutupan lahan pada areal kerja Gapoktan Sinar Mulya dapat dilihat pada gambar dibawah ini.

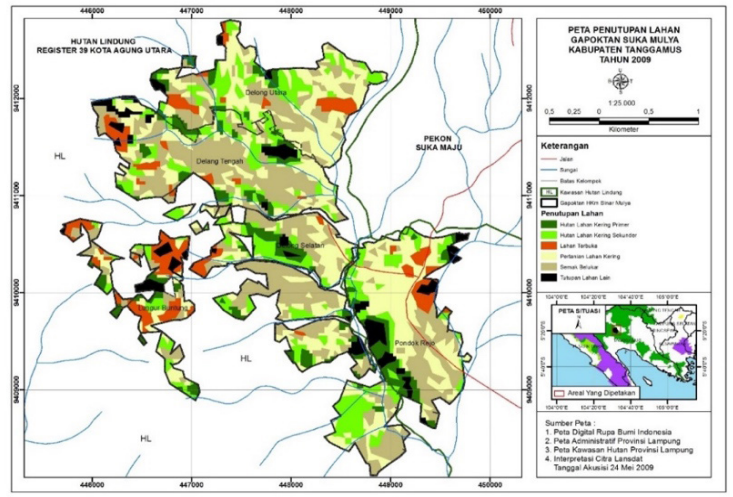

Gambar 4. Peta Tutupan Lahan Gapoktan Sinar Mulya Tahun 2009 (Sumber: Lina, 2017)

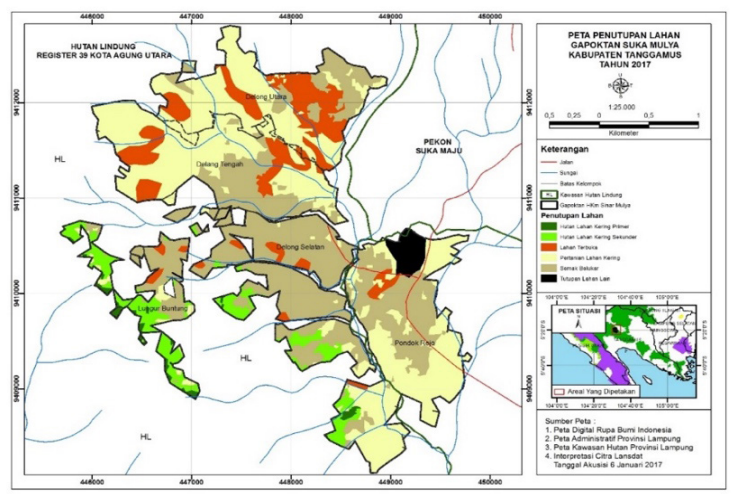

Gambar 5. Peta Tutupan Lahan Gapoktan Sinar Mulya Tahun 2017 (Sumber: Lina, 2017)

Berdasarkan data di atas dapat dilihat bahwa perubahan tutupan lahan di areal kerja Gapoktan Sinar Mulya mengalami perubahan. Pada tahun 2009 hutan lahan kering primer sebesar 61.75 ha menjadi 7.08 ha pada tahun 2017. Hutan lahan kering sekunder dari 125.96 ha menjadi 51.90 ha. Lahan terbuka pada tahun 2009 sebesar 55.57 ha meningkat menjadi 85.42 ha. Pemukiman penduduk di dalam kawasan meningkat dari 244,54 menjadi 309.66 ha. Pertanian lahan kering bertambah dari 233.87 ha menjadi 292.06 ha. Semak Belukar dari 233.87 ha meningkat menjadi 292.06 ha.
Perubahan tutupan lahan di areal kerja gapoktan disebabkan oleh semakin meluasnya areal pertanian, lahan terbuka pada areal kerja gapoktan disebabkan oleh adanya penggarap yang ingin melakukan perluasan lahan garapan. Dilihat dari grafik di atas pertanian lahan kering di areal kerja kedua gapoktan juga cenderung meningkat. Hal tersebut yang mungkin menyebabkan peningkatan ekonomi anggota gapoktan. Menurut Darmawan (2002), salah satu faktor yang menyebabkan terjadinya perubahan lahan adalah faktor sosial ekonomi masyarakat yang berhubungan dengan kebutuhan hidup manusia terutama masyarakat sekitar kawasan. (Yatap, 2008) menyatakan faktor sosial ekonomi berpengaruh dominan terhadap perubahan penggunaan dan penutupan lahan di Taman Nasional Gunung Halimun Salak (TNGHS) adalah kepadatan penduduk, laju pertumbuhan penduduk, luas kepemilikan lahan, perluasan pemukiman dan perluasan lahan pertanian.

Wijaya (2004) menyatakan bahwa faktor-faktor yang menyebabkan perubahan penutupan lahan diantaranya adalah pertumbuhan penduduk, mata pencaharian, aksesibilitas dan fasilitas pendukung kehidupan serta kebijakan pemerintah. Tingginya tingkat kepadatan penduduk di suatu wilayah telah mendorong penduduk untuk membuka lahan baru untuk digunakan sebagai pemukiman ataupun lahan-lahan budidaya. Mata pencaharian penduduk di suatu wilayah berkaitan erat dengan usaha yang dilakukan penduduk di wilayah tersebut. Perubahan penduduk yang bekerja di bidang pertanian memungkinkan terjadinya perubahan penutupan lahan. Semakin banyak penduduk yang bekerja di bidang pertanian, maka kebutuhan lahan semakin meningkat. Hal ini dapat mendorong penduduk untuk melakukan konversi lahan pada berbagai penutupan lahan.

Berkurangnya tutupan lahan di areal kerja gapoktan, menyebabkan perlunya pengawasan yang lebih ketat dari polhut dan pamhut yang bertugas di areal kerja masing-masing gapoktan. Menurut Kanninen et al. (2009) menyebutkan bahwa pengawasan yang lemah menyebabkan semakin besarnya peluang terjadi kerusakan hutan. Kondisi areal HKm yang semakin terbuka dan kurangnya tutupan lahan berupa tanaman kayu, menjadikan gapoktan harus lebih aktif dalam melakukan pendampingan terhadap penggarap dan menyarankan untuk menanam tanaman kayu atau MPTs pada areal kerja gapoktan. Meskipun telah memiliki izin HKm penggarap diharapkan tetap memperhatikan aspek konservasi di lahan HKm dengan tetap menanam tanaman kayu sesuai dengan yang ketetapan yang dalam peraturan $\mathrm{HKm}$.

\section{SIMPULAN}

Pendapatan anggota di kedua gapoktan mengalami peningkatan dari sebelum adanya gapoktan dibandingkan dengan kondisi saat ini setelah ada gapoktan. Pendapatan anggota Gapoktan Beringin Jaya mengalami peningkatan 
menjadi rata-rata Rp. 3.894.737/ha/tahun. Pendapatan anggota di Gapoktan Sinar Mulya juga meningkat dari rata-rata Rp. 5.637.376/ha/tahun.

Perubahan tutupan lahan di areal kerja Gapoktan Beringin Jaya mengalami perubahan pada areal pertanian lahan kering mengalami penambahan luas sebesar 3,23 ha yaitu dari 327.92 ha menjadi 331.15 ha. Begitupula di areal kerja Gapoktan Sinar Mulya pada tahun 2009 kondisi perubahan lahan pada pertanian lahan kering bertambah seluas 58.19 ha dari 233.87 ha menjadi 292.06 ha.

Keberadaan kelembagaan disuatu gapoktan memberikan dampak positif terhadap peningkatan pendapatan anggota, tetapi tidak bagi keberadaan lahan HKm yang mereka kelola dikarenakan tutupan hutan primer semakin berkurang dari tahun ketahun.

\section{DAFTAR PUSTAKA}

Arikunto, S. (2002). Prosedur Penelitian Suatu Pendekatan Praktek. Jakarta: Rineka. Cipta. 370 hlm.

Darmawan, A. (2002). Perubahan Penutupan Lahan di Cagar Alam Rawa Danau. (Skripsi). Bogor: Jurusan Konservasi Sumberdaya Hutan, Fakultas Kehutanan, Institut Pertanian Bogor.

Departemen Kehutanan. (1999). Diakses pada tanggal 20 Agustus 2016. Undang-Undang Republik Indonesia Nomor 41 Tahun 1999. http://www. dephut.go.id/INFORMASI/UNDANG2/ uu/41_99. Htm.

Departemen Kehutanan. (2007). Diakses pada tanggal 20 Agustus 2016. Peraturan Menteri Kehutanan nomor :P.37/Menhut-II/2007.http: //www.dephut. go.id/files/P37_07.pdf

Dien. V.T. (2004). Susceptibility to for est degradation: A case study of the application of remote sensing and GIS application in Bach Ma National Park, Tua Tien Hue Province, Vietnam [Thesis]]. The Netherlands: International Institute for GeoInformation Science and Earth Observation..

Hermanto. (2007). Rancangan Kelembagaan Tani. Bogor: Balai Penelitian dan Pengembangan Pertanian.
Kanninen. (2009). Apakah hutan dapat tumbuh di atas uang? Implikasi penelitian deforestasi bagi kebijakan yang mendukung REDD. Bogor: Perpesktif Kehutanan No 4. CIFOR.

Purwita T., Harianto., Sinaga, B.M., Kartodihardjo, H. (2009). Analisis Keragaman Ekonomi Rumah Tangga: Studi Kasus Pengelolaan Hutan Bersama Masyarakat di Pengalengan Bandung Selatan. Bandung: Jurnal Penelitian Sosial Ekonomi dan Ekonomi Kehutanan. Vol. 6 (1): 53 - 68.

Senoaji, G. (2011). Kondisi Sosial Ekonomi Masyarakat Sekitar Hutan Lindung Bukit Daun di Bengkulu. Sosiohumaniora. Vol. 13(1): 1-17.

Sinaga, D. (2016). Hubungan Sumber Daya Manusia Dan Sosial Budaya Dengan Tingkat Kesejahteraan Masyarakat Di Kecamatan Senembah Tanjung Muda Hulu Kabupaten Deli Serdang. Sosiohumaniora 18 (3): 218-226.

Sugiyono. (2007). Metode Penelitian Pendidikan Pendekatan Kuantitatif, Kualitatif dan R\&D. Bandung: Alfabeta.

Syamsuddin, (2006). Analisis Pengaruh Karakteristik Individu Terhadap Perilaku Kepemimpinan, Kinerja Bawahan dan Pertumbuhan Usaha: Studi Kasus

Wijaya, C.I. (2004). Analisis Perubahan Penutupan Lahan di Kabupaten Cianjur Menggunakan Sistem Informasi Geografis. (Skripsi). Bogor: Fakultas Kehutanan. Institut Pertanian Bogor.

Yatap, H. (2008). Pengaruh Peubah Sosial Ekonomi Terhadap Perubahan Penggunaan dan Penutupan Lahan di Taman Nasional Gunung HalimunSalak. (Tesis). Bogor: Sekolah Pascasarjana, Institut Pertanian Bogor.

Yusri, A. (2011). Perubahan Penutupan Lahan dan Analisis Faktor Penyebab Perambahan Kawasan Taman Nasional Gunung Ciremai. (Skripsi). Bogor: Departemen Konservasi Sumberdaya Hutan dan Ekowisata Fakultas Kehutanan Institut Pertanian Bogor. 